\title{
Recreational use of forests by young people
}

\author{
Jolanta Barbara Cichowska \\ University of Science and Technology in Bydgoszcz, Faculty of Civil and Environmental Engineering and Architecture, \\ Al. prof. S. Kaliskiego 7, 85-796 Bydgoszcz, Poland \\ Phone: +48 5234084 40, e-mail: jolanta.cichowska@utp.edu.pl
}

\begin{abstract}
The article is a continuation of research conducted in 2016-2017, whose goal was to determine expectations and needs of young people regarding forests. In this study, attention is focused on different preferences of high-school students and university students. Frequency and reasons for which high-school students visit forests have been studied. Forms of forest activities preferred by the respondents as well as familiarity of young people with the sanitary state of the woodlands, the role of biocoenosis in the ecosystem and its significance for people have been analysed. The respondents' knowledge of rules to be followed when being in a forest, use of its resources and major threats to this ecosystem have been studied.
\end{abstract}

Keywords: forest areas, natural and environment protection, social expectations, high school students, university students

\section{Introduction}

In the Convention on Biological Diversity, we read that in the past, timber production was regarded as the main function of forests. However, in the recent years, this perception has changed to become a more multi-functional and balanced view. Other forest functions and services, such as recreation, health and well-being, biological diversity, maintenance of ecosystem services and the mitigation of climate change, are increasingly recognised as integral components of sustainable forest management, and forest biological diversity is recognised as both a complex and a unique element.

Forests are one of the most biologically rich terrestrial systems. Forests cover approximately $30 \%$ of Earth's land surface and provide critical ecosystem goods and services, including food, fodder, water, shelter, nutrient cycling and cultural and recreational value. Forests also store carbon, provide habitat for a wide range of species and help alleviate land degradation and desertification. Therefore, forests and forest biological diversity are innately linked to ecosystem and human well-being (https://www.cbd.int...).

Pilli and Pase (2018) provided a wide description of forest functions. Through analytical approach, we can understand the interactions occurring over time between the evolution of the demands expressed by the society and the main changes in the forest landscape. When using forest resources, it is essential to make sure that they will not exhaust and can be preserved. This is the responsibility of the Polish State Forests to provide the society with free access to forests and supervise exploitation of their resources.

The aim of this study is to determine how often high-school students visit forests and for what purposes. These issues seem to be important as, according to Makris et al. (2016), leisure activities play a very important role in people's lives, because of technological progress and civilisation development, but there are more and more people who prefer passive and consumptive lifestyle that not only stands in opposition to the human nature but also inhibits psychological and physical development. It has also been established whether current development of forests and the requirements and expectations of high-school children regarding the forest and its management are met. The respondents' awareness of its functions and role has been analysed as well.

This study is a continuation of the research conducted in 2016-2017 amongst university students (Cichowska 2017). Comparison of those educational groups allows to find out similarities or differences in their approach to the resources offered by the forest and problems connected with its exploration. A thesis was accepted: the age of young people can influence their preferences as to what activities they would choose to do in the forest (whether recreational or health related). It was assumed that high-school students spend most of their time in the virtual world so forests are not attractive enough for young people to visit and more often students choose to spend leisure time more passively in home. From the scientific point of view, a comparison of both the respondent groups seems to be 
important as the way people spend their free time is an important element of the quality of their lives, which is indicated by Drozdowska et al. (2018). Providing information on the forms of spending free time in the forest (activities chosen by people of different age) is an important tip for the managers of forest areas on how to organise the forest infrastructure and what behaviours can be expected (which was given in the study).

\section{Materials and methods}

A survey carried out in Bydgoszcz in 2019 on a group of 428 three-year general high-school students. The survey was based on questionnaires handed directly to the respondents in the classroom during a lesson. The survey was carried out with headmasters' consent, and its date was agreed with the respondents. It was voluntary and anonymous. Young people who took part in the survey were assured that the results would be used only for cognitive purposes. An advantage of the applied method was the elimination of interviewer's influence, which according to Sołoma (2002) encourages the respondents to provide straight answers even to sensitive questions. At the same time, it provides the possibility to obtain significant uniformity of materials. The choice of the population sample was supposed to provide opinions of high-school students (representing the level of middle education) of a given age (17-18 years old), which were compared with the opinions of a group of college students who had been analysed before (19-24 years old) (Cichowska 2017). As the surveyed populations were more homogeneous and divided into two statistical categories, the statistical sample could be smaller. In sociology, according to Sołoma (2002), the surveyed population should include not fewer than 100 persons. The study assumes that the respective population is comparable with the group of college students who had been surveyed 2 years before.

The purpose of the survey was to find out whether young people

1. treat the forest as an element of the environment that offers them concrete social and health benefits,

2. visit forests in different seasons, not only in summer (on vacation),

3. know how to safely use forest resources,

4. can provide assessment of the stands in the nearest environment and determine the importance of forests in maintenance of the earth eco-balance

5. can indicate which facilities should be introduced to encourage them to spend more time in these ecosystems.

The questionnaire consisted of 31 questions, 5 of which were of open formula. Contrary to the questionnaire prepared for university students, it included explanation of terms such as survival, monoculture and tuft. In addition, the respondents were asked when choosing a holiday destination in 2018, whether they took into consideration places situated close to a forest or spent leisure time in the forest without being on holiday. Eventually, less than 150 questionnaires were received (578). Such a situation was caused by poor involvement of high-school students, as compared to university students ( 578 persons) in the research process (refusal to take part in the survey) or partial completion of questionnaires. It was explored (using Pearson correlation coefficients $r$ ) to what degree the variables (including facilities provided in the forests or obstacles to active rest; poor marking of tourist trails; lack of adequate infrastructure; disorders, trash and no protection from other people's bad behaviour) affected the overall frequency of young people's visits to forests in different seasons. In addition, it was investigated whether the respondents' preferences for the structure of stands (deciduous, coniferous or mixed) or whether its location on the territory of their communes (in the vicinity or far from the place of their residence) is related to the choice of a forest they would like to spend time. In order to verify reliability of the calculated Pearson correlation coefficient, a nonparametric significance test of the correlation coefficient was carried out. Then, it was possible to find out with pre-accepted probability whether the correlation is statistically significant. The author of this study is aware of the fact that the issue connected with recreational use of forests by young people is a complex one. According to Gołos (2010), an analysis of the process of sensual perception of a widely understood natural environment, including forest eco-systems, as well as preferences and social expectations from the woodlands and from their administrators, is a complex task (disciplines such as social psychology and sociology need to be taken into account). Therefore, the initial survey will be followed by more precise and detailed ones to provide a better understanding of the analysed phenomenon.

\section{Results and Discussion}

Amongst 428 respondents who eventually took part in the survey, $70.5 \%$ were city residents, mainly from Bydgoszcz (91.4\%; the remaining persons inhabited rural areas and commuted to schools in Bydgoszcz). The age structure was dominated by 17,16 and 18 years old respondents $(39.2 \%$, $28.7 \%$ and $23.5 \%$, respectively). Only 306 persons $(71.5 \%$ of all respondents) provided their age. The purpose for which young people go to the forest is to do physical activities (walks: 43.9\%), relax (escape from everyday life: $33.6 \%$ ) and tighten relations with others (meeting friends: $30.3 \%$ ). In comparison with the survey carried out 2 years earlier, it was observed that high-school students, more often than university students, treat the forest as a place to have a good time $(28.5 \%)$ and meet friends (30.4\%). Academic youth, in turn, more often declared visiting a forest to pick up mushrooms (37\%), forest fruits $(9.3 \%)$ or admire beautiful views $(30.1 \%)$. They more often go to forests in the company of their families $(16.6 \%)$ to practice sports $(29.4 \%)$ (Fig. 1$)$. When asked what were the biggest benefits of forests, the respondents indicated peace and quiet (39.1\%), similar to students (40.5\%). This year's respondents have added that they can fully relax only when there are no other forest users around (24.1\%), whereas university students declared that it was clean and healthy 
air that was most attractive for them (25.2\%). Although the high-school respondents do not give priority to the argument indicated by college students, they do agree that the primary function of the forest is the clean air and the oxygen it provides $(52.7 \%)$. They also give priority to the forest recreational and tourist functions $(30.7 \%)$ over protection of its natural values (16.1\%) (students' answers were opposite). According to Gołos (2010), the forest function to improve the quality of air was also given priority, putting the recreational function (similar to that in the nationwide investigations) in the third place. The above observations prove that young people are aware of the fact that forests contribute to the process of air cleaning from heavy metals and dusts and they absorb noise (Raport o stanie lasów...2019). Thus, they visit forests in search of mental relaxation, although their motivation is different (e.g. going for solitary walks or in the company of friends). These can be age-related choices between given priorities and activities (Dubis 2014). These aspects are also addressed by Gołos (2013), according to whom the use of forest is additionally affected by factors such as lifestyle, increased mobility and free access to forests.

No differences were found in the frequency of visiting the forest by university students and high-school students. They rather do not spend much time in the forest in winter $(22.4 \%$ vs $20.8 \%$ ) but go there usually once or twice in this season $(16.6 \%$ vs $20.1 \%)$. Forests are more attractive for them in the spring and summer; so, during this time, they visit them even a few times a week (but high-school students who come from rural areas go there every day, $15.4 \%$ ), whereas, in the fall, the contact with the forest environment is limited to one or two visits (Table 1). Although, in this respect, the results obtained for both groups are very similar, it has been observed that there was a group of high-school students (contrary to academic youth) who spent no time in the forest in the summer ( $7.7 \%$ vs $2.8 \%)$. The survey has revealed that high-school student spend so little time in the forest in the fall or winter because there are not enough facilities that they need to have a good time and engage in recreational activities or sports (correlation coefficient was found to be 0.444 and

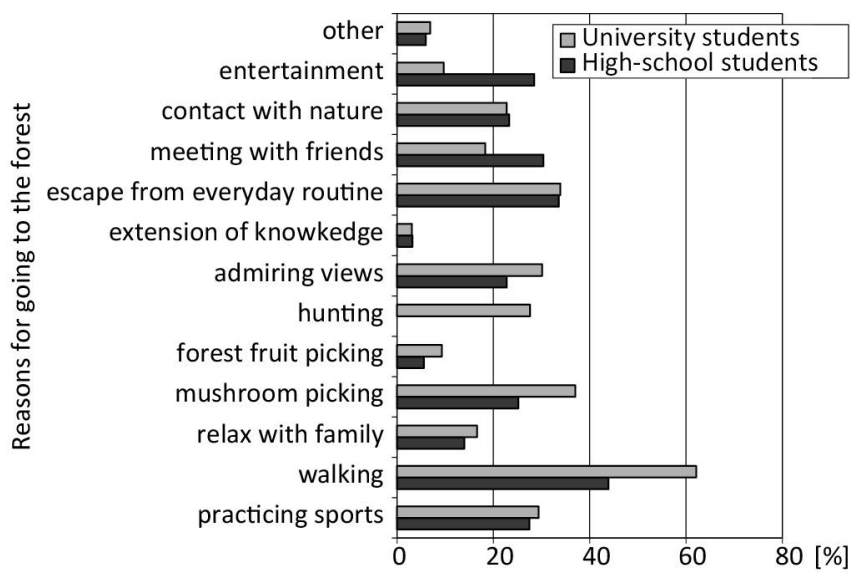

Figure 1. Reasons for which high-school students spend time in the forest (in compparison with university students)
0.386 , respectively). Moreover, it has turned out that young people are discouraged from visiting a forest in any season (on a daily or weekly basis) by obstacles such as incorrect marking of trails, lack of appropriate infrastructure, lack of safety sense and disorder (here, correlation dependence was found to be 0.596 and 0.592 ). It is hard to say whether the location of a forest near the place of residence translates into frequency of visits. On an average, the distance was $5 \mathrm{~km}$ (for university students, it was longer by $0.9 \mathrm{~km}$ ). The location of a forest certainly does not have any significant influence on the preferable structure of its stand (Pearson linear correlation coefficient $r$ was 0.291). Respondents spend leisure time mainly in forests situated on the territory of their comunes (49.6\%), and the forest type (coniferous forest: 6.6\%; deciduous: $9.9 \%$; mixed: $18.4 \%$ ) has not much significance for them $(65.1 \%)$. However, according to the initial surveys carried out by Chojnacka-Ożga and Ożga (2017), the structure of the stands has an impact on bioclimatic conditions, human warmth sensation and the possibilities of spending time actively. Wajchman-Świtalska (2019) provided some interesting observations in this area as well. The author's own research showed that the kind of activity to be undertaken by young people largely depends on the facilities the forest can offer (pedestrian and bike trail marking, bonfire places, observation decks, educational paths, horse riding tracks, sheds with benches, information boards, tables and benches, trash bins and parking lots). Here, a correlation was found (high correlation) at the level of 0.614 , reported for college students (0.646). They engage in these activities mainly with friends $(51.4 \%)$ or family $(25.2 \%)$. They often go hiking in the forest on their own $(31.8 \%)$ or with a sports group $(8.9 \%)$, and only some of them $(0.5 \%)$ hike with a trourist group in continuation of their recreational interests.

Activies that the high-school students choose whilst spending time in the forest do not differ significantly from those chosen by university students (Table 2), except for survival, that is, ability to survive in difficult forest conditions $(8.3 \%$ vs $3.6 \%)$. According to 'Forest Survival' (Leśny survival), a publication released by the State Forests Information Center (2017), such a project is undertaken to test one's strength and deepen knowledge of 'how to get through hard times' and practice skills that lead to self-recognition and the contact with the surrounding nature. It is possible that school children choose such activities to overcome their weaknesses. In this way, they can also be more creative, independent and enjoy more freedom than in everyday life.

To be able to engage in their favourite activities in the forest, high-school youth expect more facilities to be provided by the State Forests. Their preferences vary significantly from those declared by university students (Fig. 2). What high-school students count on is primarily a well-arranged tourist infrastructure, that is, biking trails (35.5\%), which lead to places equipped with sheds, benches $(45.8 \%)$ or tables or benches alone (37.4\%). Similar demand for tourist infrastructure was reported by the respondents described by Sławski and Sławska (2009). Besides, they would like to have the 
Table 1. Frequency of school youth visits to the forest in different seasons (in comparison with college students)

\begin{tabular}{|c|c|c|c|c|c|c|c|c|}
\hline \multirow[b]{2}{*}{ Specification* } & \multicolumn{2}{|c|}{$\begin{array}{c}\text { Winter } \\
\text { (XII-II) }\end{array}$} & \multicolumn{2}{|c|}{$\begin{array}{l}\text { Spring } \\
\text { (III-V) }\end{array}$} & \multicolumn{2}{|c|}{$\begin{array}{c}\text { Summer } \\
(\mathrm{VI}-\mathrm{VIII})\end{array}$} & \multicolumn{2}{|c|}{$\begin{array}{l}\text { Autumn } \\
\text { (IX-XII) }\end{array}$} \\
\hline & $\begin{array}{l}\text { High- } \\
\text { school } \\
\text { students }\end{array}$ & $\begin{array}{l}\text { University } \\
\text { students }\end{array}$ & $\begin{array}{l}\text { High- } \\
\text { school } \\
\text { students }\end{array}$ & $\begin{array}{l}\text { University } \\
\text { students }\end{array}$ & $\begin{array}{l}\text { High- } \\
\text { school } \\
\text { students }\end{array}$ & $\begin{array}{l}\text { University } \\
\text { students }\end{array}$ & $\begin{array}{l}\text { High- } \\
\text { school } \\
\text { students }\end{array}$ & $\begin{array}{c}\text { University } \\
\text { students }\end{array}$ \\
\hline \multicolumn{9}{|c|}{ Answers [\%] } \\
\hline Once a week & 7.4 & 7.3 & 10.3 & 11.0 & 9.6 & 12.4 & 10.6 & 10.7 \\
\hline Twice a week & 2.9 & 3.8 & 9.3 & 10.0 & 8.2 & 9.3 & 7.3 & 7.2 \\
\hline A few times a week & 5.7 & 7.3 & 17.1 & 13.2 & 25.1 & 21.2 & 11.6 & 11.4 \\
\hline Once or twice in the season & 16.6 & 20.1 & 14.6 & 12.8 & 10.2 & 8.6 & 14.5 & 15.9 \\
\hline Once a year & 10.6 & 13.1 & 4.4 & 6.9 & 3.4 & 6.3 & 7.3 & 6.5 \\
\hline Not at all & 22.4 & 20.8 & 7.8 & 9.0 & 7.7 & 2.8 & 11.6 & 10.4 \\
\hline Total* & 412 & 578 & 410 & 578 & 414 & 578 & 414 & 578 \\
\hline
\end{tabular}

* Respondents answers in total; school students did not provide answers to all questions, therefore, the number of surveyed persons in particular columns equals 428

Table 2. Recreational activities chosen by school youth (compared to university students' responses)

\begin{tabular}{|c|c|c|c|c|c|}
\hline \multirow{2}{*}{ No. } & \multirow{2}{*}{$\begin{array}{l}\text { Preferred forms of } \\
\text { recreation }\end{array}$} & \multicolumn{2}{|c|}{ High-school students } & \multicolumn{2}{|c|}{ University students } \\
\hline & & number of indications & {$[\%]$} & number of indications & {$[\%]$} \\
\hline 1. & Biking & 256 & 26.6 & 394 & 29.9 \\
\hline 2. & Hiking & 304 & 31.6 & 474 & 36.0 \\
\hline 3. & Gimnastics & 18 & 1.9 & 26 & 2.0 \\
\hline 4. & Fishing & 62 & 6.4 & 54 & 4.2 \\
\hline 5. & Hunting & - & - & 18 & 1.3 \\
\hline 6. & Geocaching & 18 & 1.9 & 16 & 1.2 \\
\hline 7. & Mountain hiking & 70 & 7.3 & 100 & 7.6 \\
\hline 8. & Mountain climbing & 16 & 1.7 & 18 & 1.3 \\
\hline 9. & Nordic walking & 26 & 2.7 & 24 & 1.8 \\
\hline 10. & Horseriding & 24 & 2.5 & 24 & 1.8 \\
\hline 11. & Survival & 80 & 8.3 & 48 & 3.6 \\
\hline 12. & Orienteering & 68 & 7.1 & 90 & 6.9 \\
\hline 13. & Cross-country skiing & 10 & 1.0 & - & - \\
\hline 14. & Others & 10 & 1.0 & 30 & 2.4 \\
\hline \multicolumn{2}{|c|}{ Total number of indications* } & 962 & 100 & 1316 & 100 \\
\hline
\end{tabular}

* Respondents could mark more than one form of recreation 
possibility to light a bonfire (37.4\%) and stop in vantage points (34.5\%). Apart from aesthetic values, they expect clean and well-maintained forests; hence, availability of trash bins is indicated on the second position (38.3\%). They count on promotion-information and educational materials in the form of leaflets or books with maps (33.1\% vs $28.5 \%)$, laminated maps $(16.8 \%)$, folders $(12.1 \%)$ and atlases $(6.1 \%)$. Only $2.3 \%$ of the respondents have no expectations from forestry management.

According to the respondents, the main obstacle to choosing active recreation in the forest is its contamination with different kinds of trash (65.4\%). Young people are aware that 'illegal dumps' pose a serious threat to the natural environment, and they have knowledge of the condition of the nearby forests. A significant group of students, as many as 336 respondents ( $79.6 \%$ out of 422 responses), shared that the health of forests near the place of their residence is good $(66.6 \%)$ or bad $(22.6 \%)$. Only $9 \%$ of the respondents said that it was very good, and $1.8 \%$ said it was very bad. At this point, it needs to be emphasised that it was a subjective assessment of the respondents. Determination of symptoms and causes of tree damage requires monitoring (Stan zdrowotny lasów polskich w $2017 \mathrm{roku}$ ). According to high-school students, serious obstacles to move in the forest are poor trail marking $(19.6 \%)$, lack of protection against other people $(19.1 \%)$ or the above-mentioned infrastructure (12.6\%). Some other responses appeared (6\%), including lack of time, technological devices which keep them home and prevent from enjoying the nature or tick worms which threaten human health. Although high-school students did indicate trash as the main factor that discourages them from spending time in the forest, they do not think that it is a major obstacle because they indicate it at the ninth position (Table 3). First of all, according to the survey carried out by Skłodowski et al. (2013), fires were of much less importance in the ranking of forest threats (including their pollution). There, the respondents indicated vandalism, vehicle traffic and scaring animals as the biggest threats posed by forest users.

Only 4 threats were classified by both school students and academic youth at the same positions, whereas 2 of 15 were in completely different positions. School students thought that increased exploitation of forests by tourists and forest fruit pickers (third position) is more dangerous than illegal trash dumping (ninth position). According to Jalinik (2016), they may have noticed a trend ('tourist-recreational attractiveness' and 'come back to nature') indicating a tendency of more intensive use of forests by tourists and forest fruit pickers. The author emphasises the threat posed by the development of tourism involving an increase in human activity including environment pollution, distortion and degradation of forest settlements, stands, flora and fauna. In turn, the problems connected with forest fruits pickers is explicitly described by Nowacka et al. (2017), who even proposed to impose fees on inhabitants of areas situated near the forest, whose welfare and also financial means largely depend on the forest resources such as mushrooms of forest fruits and

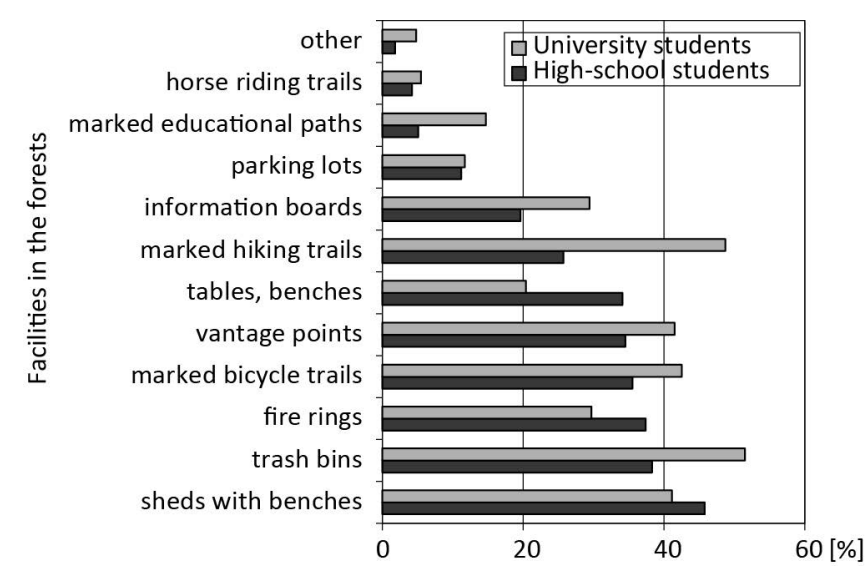

Figure 2. Facilities that are expected to be found in the forest by school youth (as compared to university students)

Table 3. Ranking of the main (major) threats to forests indicated by school students (as compared to university students)

\begin{tabular}{|c|c|c|c|}
\hline \multicolumn{4}{|c|}{ Main threats to forests indicated by: } \\
\hline & Iigh-school students & & University students \\
\hline 1. & Fires & 1. & Fires \\
\hline 2. & Illegal logging & 2. & Illegal trash dumping \\
\hline 3. & $\begin{array}{l}\text { Intensive exploitation } \\
\text { by tourists and forest } \\
\text { fruit pickers }\end{array}$ & 3. & Illegal logging \\
\hline 4. & Droughts & 4. & Droughts \\
\hline 5. & Land development & 5. & Land development \\
\hline 6. & Poaching & 6. & Poaching \\
\hline 7. & Air pollution & 7. & Air pollution \\
\hline 8. & Parasite fungi & 8. & Monocultures \\
\hline 9. & Illegal trash dumping & 9. & Strong winds \\
\hline 10. & Strong winds & 10. & Insect pests \\
\hline 11. & Insect pests & 11. & $\begin{array}{l}\text { Intensive exploitation } \\
\text { by tourist and forest } \\
\text { fruits pickers }\end{array}$ \\
\hline 12. & Monocultures & 12 . & Tuft \\
\hline 13. & Tuft & 13. & Parasite fungi \\
\hline 14. & Frost & 14. & Rodents \\
\hline 15. & Rodents & 15 . & Frost \\
\hline
\end{tabular}

herbs. However, it needs to be stressed that both high-school youth and university students are aware of the significance of these problems and can judge them appropriately. Having in mind these issues, the respondents' knowledge of the forest environment was analysed in the study (use of its resources, 
environment protection methods and basic safety rules) and an attempt was undertaken to define the young people's behaviours in the forest environment (whether their behaviours can impact the condition of forests; whether they had ever taken actions that would contribute to forest destruction or had been involved in ecological actions on behalf of forest protection). This information can be essential for education about forests. Not without a reason, the respondents were asked whether they had spent time in the forest environment in the summer season of 2018. Knowledge of these preferences can provide forestry agencies with information how to prepare varied educational and recreational offers.

Respondents realise that forests are widely accessible to the society $(65.7 \%)$, and, therefore, they need to be protected. About $28.2 \%$ of the respondents have no opinion on this subject, whereas $6.1 \%$ declare that the access is limited. What is interesting, $23.8 \%$ of the respondents (100 persons) admitted to having done things that contributed to devastation of forests (30; more than college students). Those bad behaviours could later motivate them to take part in some actions on behalf of the forest environment (cleaning up the earth: $43.6 \%$; cleaning up forests: $41 \%$; planting trees under supervision of a forester: $10.2 \%$; help in tree trimming: $5.2 \%$ ), as a full correlation was found in this respect to be equal to 1 . High-school children think that positive behaviour and appropriate attitude can have a good impact on the condition of forests ('definitely yes': $28.5 \%$; 'rather yes': $32.8 \%$ ). As many as $61.8 \%$ of the respondents were involved in different actions organised for the protection of forests. High-school students' knowledge of forests can raise concern, especially that only 32 persons could adequately define law-protected forms of nature on the territories of the State Forests. National parks and monuments of nature were indicated by 10 respondents, and landscape parks and protected animals, plants and mushrooms were mentioned by 6 persons. Probably, the respondents were not familiar with the term 'environment protection forms', because they provided answers including actions that should be taken to protect the forests (introduction of different types of warnings, information boards, fencings, ban on hunting and poaching, increasing the number of forest patrols, high penalties for dumping trash and ban on entering the forest). Only 3 respondents attempted to answer the question concerning the role of Forest Promotion Complexes, saying that they promote the rules of ecodevelopment and sustainable forest management, perform educational function for young people and are promoted by forestry agencies. Most of them did not know (45.2\%) or definitely said ('no': $26.2 \%$ ) that hunting is an element of environment protection, which is set out in the Hunting Law Act of 1995 (wild animals are common benefit and belong to the State Treasury and game management is the responsibility of foresters and hunters associated in the Polish Hunting Association, according to the rules of sustainable development and rational forestry, fishery and agriculture management). The respondents found it difficult to answer the question: how far from a forest open fire can be used? Only 112 persons ( $33 \%$ of 330 answers) indicated that the distance is $100 \mathrm{~m}$ from the forest. It is concerning that for 110 respondents, the distance was much smaller than $100 \mathrm{~m}$, which can indicate their ignorance of basic safety rules (set out in art. 30 item 3 sec. 5 of Forestry Act). It is permitted to fire up a grill and a bonfire only in specially prepared and supervised locations that are appropriately secured and the risk of spreading fire is reduced to minimum. The other respondents were probably aware of this because they indicated further distances (100-200 m: 146 persons; $300-500 \mathrm{~m}: 50$ persons; 600-800 m: 4 persons; $900-1000 \mathrm{~m}: 10$ persons and more than $2000 \mathrm{~m}: 8$ persons). The average distance was $166 \mathrm{~m}$. The respondents' knowledge on how to use forests for horse riding was much better because they knew that it is allowed only on trails determined by the forester $(58.5 \%)$, which is set out in art. 29 item 1a of Forestry Act. However, there are many restrictions to horse riding because it poses numerous threats (both of chemical and physical character), thus horse riders cannot use all forest paths $(24.2 \%)$, except for biking trails, which was confirmed by $17.3 \%$ of the respondents. Being concerned about the natural environment and its aesthetics, needs and safety, Kacprzyk and Rother (2013) provided major rules for using horse riding trails, emphasising that they should be constantly monitored. This will allow to avoid damage to the surface, losses in forest resources or reduction of rain fall infiltration.

In terms of activities that involve using the forest resources, high-school students indicated acquisition of timber $(52.3 \%)$, plants and their elements for the needs of pharmaceutical industry (42\%). Furthermore, they listed collection of forest fruits (37.4\%), acquisition of trees for Christmas $(28 \%)$ and exploitation of fossils $(9.3 \%)$. Management of the Polish forests is well planned and rational. The State Forests undertake investments to increase the forest areas, thanks to which our country is at the top position in Europe. According to the information provided on the official website of the State Forests, the area of forests in Poland is 9.2 million ha, which means $29.6 \%$ coverage (www.lasy.gov.pl). As many as $32.9 \%$ of the respondents gave the value. The remaining respondents were not able to provide an answer on this subject $(17.6 \%)$ or gave incorrect values, $22.9 \%$ (13.3\% persons) or $33.9 \%$ (36.2\% persons). Secondary school students such as spending leisure time in the forest, which was confirmed by 206 respondents $(67.3 \%)$, who in 2018 chose to spend vacation in destinations located near the forest. The remaining students (100 persons) did not have an opportunity to go on summer vacation and were not interested in any activities in the nearby woods (64\%) or were not on holiday at all, but instead, they visited forests located near places of their residence $(36 \%)$. The survey shows that high-school children prefer to spend summer vacation in the city (58.2\%) (by comparison $63.2 \%$ of university students choose to go on vacation to the countryside). An interesting observation noted in the survey is that respondents declared that they had used agritourist farms $(38.2 \%)$ - which are thought to play a very important role in the educational process of high-school youth (including knowledge about forests). Mitura and Buczek-Kowalik 
(2016) focused on this issue, observing that educational activity is a new function of agritourism development, focused on promotion of rural areas and propagation of knowledge about these areas (including its natural values). Furthermore, following Kmita-Dziasek (2011), he added that agritourist educational farms provide a new innovative approach to education combining theory with practice. According to $23.5 \%$ of the respondents, this non-agricultural economic activity can improve ecological awareness of young people, particularly regarding importance of forests for the society and preserving biological diversity. The respondents said that contact with nature has a positive impact on their behaviour; it allows to look at the world from a wider perspective and appreciate the importance of forests for environment protection and people's welfare. About $61.8 \%$ of the respondents had contact with agritourist farms over previous 2 years (similar results were found for academic youth, $68.1 \%$ ) and $61.5 \% \mathrm{did}$ not provide any information on the educational function of agritourism, whereas $13 \%$ were sure that agritourism is not involved in educational activity. To sum up, it should be said that after Kikulski (2011), the use of forests for recreational purposes should, apart from legal regulations on staying and moving in these areas, take into consideration recreational development of these areas that needs to consider both limited resistance of woodlands to the pressure of tourism and preferences of their users.

\section{Conclusion}

The survey results have shown that:

1. There is a need to conduct further research for different social groups who use forests, as it has been observed that preferences of high-school students and university students differ in many respects. Both groups feel the need to get away from everyday life routine to spend time in a quiet and peaceful forest environment. However, high-school students are interested in recreation combined with entertainment and fun, whereas university students are more willing to have contact with nature and have direct access to its resources and benefits (e.g. mushroom picking). These preferences of young people found reflection in the way they perceived the main functions of the forest.

2. Differences in the attitude of the respondent groups regarding the needs and expectations from forests can be caused by different lifestyles and a different approach to recreation. Preferences of high-school children and university students for location of the place for resting (towns or the countryside) translate into the percentage of forest users during holidays.

3. The thesis assumed by the author of the study that school youth visit forests less often than university students (because of age and the value hierarchy) for recreational and relaxing purposes, has not been confirmed. No statistically significant differences in frequency of visits to forests in different seasons were found for the respondent groups. Both groups visit woodland most frequently in the spring and in the summer, as many as a few times in a week. This is due to better weather conditions (as compared to the autumn and winter) and holiday season which provides more leisure time.

4. According to the respondents, trash and pollution are the major obstacles that prevent them from spending time in the forest. This means that they closely observe the environment they live in. They must have recognised that the tourists who visit woodlands are more responsible for their contamination than those who illegally dump waste in the forest. This is reflected by ranks given to those threats ( 3 and 9 , respectively).

5. Forest management does not meet all the needs of the respondents in terms of recreation. The forests administrators are expected to implement a number of infrastructural facilities that will encourage them to stay in a forest for a longer time. Young people are aware that being in a forest they need to comply with certain rules and behave accordingly.

6 . The respondents usually use forests in the company of their friends, choosing to visit those situated near the place of their residence. Their preferences for the stands were insignificant for the way of relaxing.

7. High-school students are well aware of their needs and expectations regarding forests; however, they need to acquire more information about safely spending time within the forest, as well as the knowledge of how to use precious resources and objects strictly protected by law.

\section{Conflict of interests}

The author declares lack of potential conflicts.

\section{Source of funding}

The research was financed from the author's own resources.

\section{References}

Cichowska J. 2017. Demands, preferences and expectations of academic youth regarding recreation in the forest. Infrastruktura i Ekologia Terenów Wiejskich IV/2: 1529-1543. DOI 10.14597/ infraeco.2017.4.2.116.

Chojnacka-Ożga L., Ożga W. 2017. Ocena warunków wypoczynku człowieka w lesie o różnej strukturze w świetle wybranych wskaźników bioklimatycznych. Studia $i$ Materiały Centrum Edukacji Przyrodniczo-Leśnej w Rogowie 52(3): 53-60.

Drozdowska M., Leśniak-Johann M., Marak J. 2018. Wykorzystanie czasu wolnego przez studentów wrocławskich uczelni. Wyższa Szkoła Handlowa we Wrocławiu. ISBN 978-83-946671-6-0.

Dubis M. 2014. Wartości i style życia młodzieży. Jagiellońskie Studia Socjologiczne 1: 35-45.

Forestry Act 1991. Ustawa z dnia 28 września 1991 r. o lasach (z późniejszymi zmianami).

Gołos P. 2013. Rekreacyjna funkcja lasów miejskich i podmiejskich Warszawy. Leśne Prace Badawcze 74(1): 57-70. DOI 10.2478/ frp-2013-0007.

Gołos P. 2010. Społeczne znaczenie publicznych funkcji lasu pożądany dla rekreacji i wypoczynku model drzewostanu i lasu. Leśne Prace Badawcze 71(2): 149-164. DOI 10.2478/ v10111-010-0011-4. 
Hunting Law Act 1995. Ustawa z dnia 13 października 1995 r. Prawo łowieckie (z późniejszymi zmianami).

Jalinik M. 2016. Obszary leśne w rozwoju turystyki. Ekonomia i Środowisko 3(58): 313-323.

Kacprzyk W., Rothert M. 2013. Turystyka konna w Lasach Państwowych. Studia i Materiaty CEPL w Rogowie 37(4): 263-296.

Kikulski J. 2011. Aspekty udostępniania lasów do celów rekreacyjnych. Studia i Materiaty CEPL w Rogowie 3(28): 288-292.

Kmita-Dziasek E. 2011.Wprowadzenie do zagadnień edukacji w gospodarstwie rolnym. Centrum Doradztwa Rolniczego w Brwinowie, Oddział Kraków, Kraków, 44 p. ISBN 978-83-932543-0-9.

Leśny Survival. 2017. Centrum Informacyjne Lasów Państwowych (red. A. Wikło), Warszawa, 12 p. ISBN 978-83-63895-41-9.

Makris M., Niewiadomska, M., Dulian A. 2016. Aktywność turystyczno-rekreacyjna studentów szczecińskich uczelni. Handel Wewnętrzny 6(365): 266-287.

Mitura T., Buczek-Kowalik M. 2016. Zagroda edukacyjna jako nowy produkt turystyczny (przykład województwa podkarpackiego). Annales Universitatis Mariae Curie-Sklodowska, sectio B-Geographia, Geologia, Mineralogia et Petrographia 71(2): 117-128. DOI 10.17951/b.2016.71.2.117.

Nowacka Ł.W., Staniszewski P., Gasek A. 2017. Współpraca: lasy-społeczności lokalne widziane okiem mieszkańców pobliża lasów. Studia i Materiały Centrum Edukacji Przyrodnico-Leśnej w Rogowie 50(1): 192-200.
Pilli R., Pase A. 2018. Forest functions and space: a geohistorical perspective of European forests. iForest-Biogeosciences and Forestry 11(1): 79-89. DOI 10.3832/ifor2316-010.

Raport o stanie lasów w Polsce 2018. 2019. Centrum Informacyjne Lasów Państwowych, Warszawa, 101 s. ISSN 1641-3229.

Skłodowski J., Gołos P., Skłodowski M., Ożga W. 2013. Preferencje osób odwiedzających wybrane kompleksy leśne w zakresie turystyki leśnej i organizacji wypoczynku. Leśne Prace Badawcze 74(4): 293-305. DOI 10.2478/frp-2013-0028.

Sławski M., Sławska M. 2009. Las jako miejsce wypoczynku i rekreacji-analiza oczekiwań społecznych na przykładzie gminy Rogów. Studia i Materialy Centrum Edukacji Przyrodniczo-Leśnej w Rogowie 4(23): 140-150.

Sołoma L. 2002. Metody i techniki badań socjologicznych. Wybrane zagadnienia. Wydawnictwo Uniwersytetu Warmińsko-Mazurskiego, Olsztyn, 210 p. ISBN 83-7299-202-9.

Stan zdrowotny lasów Polski w 2017 roku. 2018. Instytut Badawczy Leśnictwa, Sękocin Stary. www.gios.gov.pl/monlas/raporty/raport_2017/raport_2017.pdf [15.09.2019].

Wajchman-Świtalska S. 2019. Typ siedliskowy lasu i jego waloryzacja na potrzeby rekreacji w lasach. Acta Scientiarum Polonorum Silvarum Colendarum Ratio et Industria Lignaria 18(3): 185-191. DOI 10.17306J.AFW.2019.3.19.

www.cbd.int/forest/importance.shtml [8.04.2019].

www.lasy.gov.pl [8.04.2019]. 